Juliusz JUNDZIEŁ

(Bydgoszcz, UKW)

\title{
MORZE WYZWANIEM DLA BOGÓW I LUDZI
}

Przypuszczalnie, wśród motywów morskich w literaturze europejskiej, a na pewno wczesnochrześcijańskiej, przedstawiona poniżej sytuacja spowodowała najwięcej reminiscencji:

„I rzekł do nich owego dnia, gdy nastał wieczór: «Przeprawmy się na drugą stronę». Opuścili więc ląd i wzięli go z sobą tak jak był, w łodzi, a inne łodzie towarzyszyły mu. I zerwała się gwałtowna burza, a fale wdzierały się do łodzi tak, iż łódź się wypełniła. A On był w tylnej części łodzi i spał na wezgłowiu. Budzą go więc i mówią do niego: «Nauczycielu! Nic cię to nie obchodzi, że giniemy?» I obudziwszy się zgromił wicher i rzekł do morza: Umilknij! Ucisz się! I ustał wicher, i nastała wielka cisza. I rzekł do nich: Czemu jesteście tacy bojaźliwi? Jakże to, jeszcze wiary nie macie?"1.

Wybrałem Ewangelię Marka, ponieważ spośród analogicznych opisów Mateusza i Łukasza ma on najbardziej morski charakter, choć artystycznie najlepszy wydaje się tekst Mateusza².

Ten ewangeliczny motyw najwyraźniej zainspirował późniejszych twórców do przedstawiania Chrystusa jako doskonałego sternika (gubernator), siedzącego na rufie i sterującego, panującego nad burzami i morzem, co powoduje uratowanie łodzi. Kościół stał się przez to nawą, którą kierują sternicy - biskupi, apostołowie itp. W roli uczniów występowała załoga wiernych, a łódź znajdowała się na pełnym morzu oznaczającym życie, wstrząsana niepewnością, bezradnością i uderzeniami w nią fal pokusy. Zalewanie jej przez fale to napływ herezji, które grożą zatopieniem prawowiernym ${ }^{3}$; takiego elementu nie

${ }^{1}$ Mk 4, 35-40 (wg Biblia to jest Pismo Starego i Nowego Testamentu, wyd. Brytyjskie Zagraniczne Towarzystwo Biblijne, Warszawa 1979).

2 Por. Mt 8, 23-27; Łk 8, 22-25. W wersji łacińskiej mamy navis jako określenie środka transportu, a jezioro jako mare. Tym silniej podkreślona została morska, uogólniona, scenografia wydarzeń.

${ }^{3}$ Tę opowieść ewangeliczną rozwijały i kontynuowały apokryfy Nowego Testamentu, jak np. pochodzący z lat 460-580 Transitus Ps. Joannis Theologi 23, tłum. M. Starowieyski, ANT I/2, Lublin 1980, 568: „Odpowiadając Mateusz rzekł: «ja sławiłem i sławię Boga, ponieważ gdy byłem na statku 
ma raczej w opowieściach mitologicznych - przynajmniej okresu rzymskiego. $\mathrm{Na}$ przykład rozbudowany obraz żeglugi do Rzymu boga Eskulapa w postaci węża, w ujęciu Owidiusza, zawiera sielankową relację o mijanym krajobrazie i sytuację, w której bóg - wąż i żeglarze przeczekują burzę w porcie ${ }^{4}$.

Zamierzam przedstawić tutaj szkic problemu występowania pewnych „motywów wędrownych”, używając terminologii W. Klingnera, w odniesieniu zarówno do obrazu, który stanowił przez tysiąclecia jedną z podstaw wiary i nadziei na lepsze jutro, ocalenie z niebezpieczeństwa, jak i motywu literackiego ${ }^{5}$. Ten ostatni aspekt traktuję jako konglomerat ogólnokulturowych oddziaływań na świadomość twórców zarówno literatury klasycznej, niechrześcijańskiej, jak i chrześcijańskiej. Topos zagrożenia burzą, niebezpieczeństwa morza, piraci, żegluga dosłowna i przenośnie - „przez życie”, to elementy konstytutywne naszej świadomości, nie tylko religijnej. Nie bez podstaw przygody Odyseusza zaważyły bardziej na kształcie kultury, niż cały legion Achillesów i Hektorów, choć może to perspektywa tylko subiektywna. Zarysuję więc krótko ewolucję i recepcję motywu opanowania strachu przed burzą, zwłaszcza u filozofów i ludzi z charyzmą religijną. Następnie przejdę do innych wątków literackich w biografiach znanych osobistości, ukazujących opanowanie w trakcie niebezpieczeństw czyhających na morzu, przypominając przy okazji inne elementy kontaktów z morzem w ich życiorysach.

Opis burzy u Mateusza, stanowiący podstawę tylu rozważań u Ojców Kościoła, został poprzedzony wcześniejszymi stereotypami literackimi, ukształtowanymi w okresie klasycznej kultury greckiej, a utrwalonymi w epoce hellenistycznej. Chodzi mianowicie o eksponowanie w biografiach filozofów i innych wybitnych jednostek ich dzielności i opanowania w czasie niebezpieczeństw żeglugi morskiej. Najbardziej dyskusyjną i ciągle niezbadaną pozostaje sprawa związku Ewangelii Nowego Testamentu z Vita Apollonii Filostrata, pochodzącej z okresu po 217 r., rozpatrywanych już przez kilka pokoleń badaczy: między innymi porównywano opowieści o cudach Chrystusa i Apoloniusza. M.J.

znajdującym się na morzu wzburzonym strasznymi bałwanami, nagle chmura światła okryła zamęt burzy, uciszyła ją, mnie natomiast porwała i postawiła koło was»”. Alegoryczne interpretacje tego wydarzenia rozsiane są po całej literaturze patrystycznej: np. Origenes, Commentarius In Matthaeum V 4; Homiliae in Cantica Canticorum 2, 9; Ambrosius, Hexaemeron III 24; Expositio Evangelii secundum Lucam VI 43; Epistola 71, 5; Augustinus, In Iohannis Evangelium tractatus 25, 5; 49, 19; Enarrationes In Ps. 103, 4, 5; Sermo 361, 15; Gregorius Nazianzenus, Oratio 29, 20; Epistola 44; Joannes Chrysostomus, Commentarius in Matthaeum 49, 3; 50, 1; Petrus Chrysologus, Sermo 31/ 1, 4-6; Arnobius, Commentarius in Ps. 146; Faustus, Sermo 2; Ruriciusz, Epistolae I 13; Cyrillus Alexandrinus, Homilia Ephesi habita IV 2; zob. też: J. Jundziłł, Gubernator - realistyczne a symboliczne ujęcie problematyki morskiej u Ojców Kościoła, VoxP 10 (1990) z. 19, 817-828; tenże, Rzymianie a morze, Bydgoszcz 1991, 63-66.

${ }^{4}$ Por. Ovidius, Metamorphoses XV 622-752; recepcja krytyczna, podkreślająca nikłą wartość takich epizodów: Augustinus, De civitate Dei X 16, 2; Arnobius, Adversus nationes VII 45.

${ }^{5}$ Por. W. Klingner, Z motywów wędrownych pochodzenia klasycznego, Poznań 1921. 
Schutz analizował, w ramach paralelnych nowel o cudach, także opowieść o opanowaniu sztormu na Morzu Jońskim ${ }^{6}$ i historię burzy na jeziorze Genezaret. Sądził on, że pierwowzór obu utworów można odnaleźć w hellenistycznych bajkach i romansach lub historiach, opisujących cuda greckich taumaturgów oraz w Piśmie Świętym Starego Testamentu?

Być może nie pozbawiony znaczenia jest fakt pojawienia się także w III wieku biografii filozofów Diogenesa Laertiosa, którego dzieło było kompilacją wcześniejszych prac biografów oraz pism doxograficznych i zawierało szereg dokumentów i relacji dotyczących życia i zapatrywań filozofów poczynając od mędrców jońskich po Epikura. Dla nas ważne jest przede wszystkim to, że korzysta on z o wiele starszych źródeł, jak np. z dzieła Hipponaksa - poety z VI wieku prz. Chr., czy Posejdoniosa z Apamei - historyka żyjącego w latach ok. 135-50 prz. Chrystusem. Pewne znaczenie ma także fakt, że jego biografie dotyczą wyłącznie filozofów żyjących przed Chrystusem ${ }^{8}$.

Najbardziej klasyczna i zbliżona do obrazu z Ewangelii jest anegdota o Pyrronie z Elidy, żyjącym prawdopodobnie w latach 376-286. Wyrażał on przekonanie o niepoznawalności istoty rzeczy, niemożności trafnego rozstrzygania jakiejkolwiek kwestii z powodu ułomności poznania zmysłowego oraz równoważności sądów logicznych. Jedynie sceptycyzm zapewni więc, według niego, szczęście; daje bowiem spokój (apatheia) osiągany właśnie przez powstrzymywanie się od kategorycznych sądów. Diogenes zilustrował to w następujący sposób:

„Posejdonios opowiada o nim następującą historię. Gdy towarzysze podróży, z którymi płynął okrętem, podczas burzy wpadli w przygnębienie, Pyrron zachował spokój i wszystkich pokrzepiał na duchu; wskazując na świnkę, która się spokojnie pożywiała, powiedział: «Patrzcie, przyjaciele, tak niewzruszony musi być mędrzec w podobnych wypadkach»"

Powołanie się na Posejdoniosa wskazuje na stosunkowo wczesną datę powstania tej anegdoty.

Ewangeliczny opis jest zastanawiająco zbieżny z sytuacją, w której znalazł się Pyrron. Burza morska u Posejdoniosa to burza „morska” na jeziorze Ge-

${ }^{6}$ Por. Philostratus, Vita Apollonii IV 13.

${ }^{7}$ Zreferowane za: M. Józefowicz-Dzielska, Vita Apollonii Filostrata i jej związi z literatura wczesnochrześcijańską (stan badań), SACh 2 (1980) 128-136, spec. 134; taż, Apolloniusz z Tiany. Legenda i rzeczywistość, Kraków 1983; Żywot Apolloniusza z Tyany, wstęp i tłum. M. Szarmach, Toruń 2000, 7-24; zob. też M. Szarmach, Dion z Prusy, Toruń 1979 (o paralelach między NT a utworami Diona, których naliczono około 1500).

${ }^{8}$ Por. T. Sinko, Historia literatury greckiej, III/1, Warszawa 1951, 596-597 (Diogenes). Wszystkie cytaty wg Diogenes Laertios, Żywoty i poglądy stynnych filozofów, thum. I. Krońska K. Leśniak - W. Olszewski - B. Kupis, Warszawa 2004.

${ }^{9}$ Diogenes Laertios, Vitae philosophorum IX 11, 68, tłum. Żywoty s. 557; o Pyrronie, sceptycyzmie i Posejdoniosie por. A. Krokiewicz, Arystoteles, Pirron i Plotyn, Warszawa 1974, 95-159; G. Reale, Historia filozofii starożytnej, III, tłum. E. Zieliński, Lublin 1999, 449-518. 
nezaret. Już to pobieżne przedstawienie przemawiałoby za pochodnością sytuacji biblijnej, ponieważ burza na jeziorze przedstawiona jest jako morska. Można to jednak zanegować przy pomocy opinii Augustyna, który uważał, że język Pisma Świętego oznacza terminem ,,morze” także wszelkie duże nagromadzenie wód ${ }^{10}$. Analogia zrozumiała jest również dlatego, ponieważ falowanie podczas gwałtownego wiatru na zamkniętym, stosunkowo płytkim akwenie, może być równie niebezpieczne jak morska burza. Podobne jest także przygnębienie, brak wiary w przetrwanie wszystkich przebywających na statku oraz niewzruszoność filozofa.

Spokój, a nawet sen Chrystusa, jest naturalny, ale sytuacja służy egzemplifikacji potrzeby wiary w każdej sytuacji; podobnie niewzruszoność Pyrrona staje się ilustracją jego poglądów sceptycznych. Założone wstępnie podobieństwa są więc widoczne. W sytuacji biblijnej Apostołowie właściwie nie mają jednak powodów do obaw, skoro Jezus jest z nimi, a inne łodzie płynęły obok i mogły udzielić im pomocy. Natomiast w pełni uzasadniony był niepokój podróżnych na statku Pyrrona, którzy, tak jak większość mieszkańców basenu Morza Śródziemnego, mieli w pewnym stopniu zakorzeniony lęk przed niebezpieczeństwami grożącymi na morzu ${ }^{11}$. Odmienne natomiast jest zakończenie: Pyrron powołuje się niezbyt zgrabnie na spokojne zachowanie się zwierzęcia, co jest po prostu bezmyślnością, natomiast Chrystus gromi uczniów za niedostatek wiary.

Dowcipnym komentarzem do tej sytuacji jest seria żartów, dotyczących absurdalnego zachowania pseudo mędrców w czasie burzy: jeden z nich pociesza płynących z nim niewolników tym, że zapisał im wolność w testamencie; inny nie wyrzucał, jak współpasażerowie, bagażu za burtę dla odciążenia statku, tylko zmniejszał sumę w skrypcie dłużnym; kolejny - tym, że mimo wysokiej opłaty za przejazd, cierpi te same niedogodności, co załoga ${ }^{12}$.

Wpływ tego schematu zachowania filozofa widać już w Dziejach Apostolskich, kiedy to Paweł uspokajał podróżnych wielkiego zbożowca, każąc im

${ }^{10}$ Augustinus, De Genesi contra Manichaeos I 12, 18, thum. J. Sulowski, PSP 25, 32: „w języku hebrajskim wszelkie zbiorowisko wody czy to słonej czy słodkiej nazywa się morzem". Geograficzny opis jeziora por. E. Dąbrowski, Nowy Testament na tle epoki, Poznań - Warszawa - Lublin $1965,22-24$.

11 Por. J. Delumeau, Strach w kulturze Zachodu XIV-XVIII wieku, thum. A. Szymanowski, Warszawa 1986, 35-50; Jundziłł, Rzymianie a morze, s. 139-147. Wersję przygody Pyrrona opisuje także Plutarch (zob. Quomodo quis in virtuti. Moralia 11,82F), brak tu jednak istotnego momentu niepokoju pasażerów, który tak przybliża anegdotę do sytuacji ewangelicznej: „A o Pyrronie powiadają, że na statku w czasie niebezpiecznej burzy morskiej wskazał prosiątko, które z zadowoleniem pożywiało się rozsypanym jęczmieniem, i rzekł do towarzyszy, że z rozumu i filozofii powinni czerpać taką właśnie niewzruszoność, jeżeli nie chcą dać się niepokoić życiowym zdarzeniom" (tłum. Z. Abramowiczówna: Plutarch, Moralia: Jak można stwierdzić własny postęp w cnocie, Warszawa 1979, 60).

12 Por. Philogelos 25, 80-81; 255 - znaczącym faktem jest, że pochodzą one z epoki późnej, literacki wzorzec zdążył się więc utrwalić. 
wierzyć w ocalenie z pomocą Bożą oraz demonstrując spokój przez zwykłe spożywanie posiłków (por. Dz 27, 9-44; 27, 33-34). Podobnie, choć wobec burzy in spe, zachował się Demonaks, filozof cynicki z czasów Hadriana: na pytanie czy nie boi się wypłynąć w podróż w czasie zimy, gdy, mówiąc dosadnie, w wyniku katastrofy może być pożarty przez ryby, odpowiedział:

„Toż byłbym [...] niewdzięcznikiem, gdybym się nie pozwolił rybom spożyć, których sam tyle skonsumowałem!"13.

Nie tylko filozofom przystało tak się zachowywać, ale i wielkim wodzom, czego przykładem jest Pompejusz. Z sytuacji, w której się znalazł, w obiegu kulturowym pozostało tylko słynne „navigare necesse est”, natomiast nie pamięta się, że tymi słowami Pompejusz zachęcał marynarzy, by podjęli żeglugę w czasie burzy, która rzekomo przeraziła nawet ludzi zawodowo związanych z żeglugą ${ }^{14}$.

Gorszymi nie powinni być święci i Ojcowie Kościoła, ale w ich życiorysach z okresu cesarstwa rzymskiego ten motyw prawie nie występuje poza nielicznymi, przypadkowymi wątkami. Na przykład obecność św. Marcina na statku sprowokowała pewnego poganina do wołania o pomoc w czasie burzy do „Boga Marcina” i burza natychmiast się uspokoiła, co Sulpicjusz przypisał mocy Marcina ${ }^{15}$. Grzegorz z Nazjanzu i Paulin z Noli przeżywali burze grożące zatopieniem statków. Utrwaliło to ich wiarę, u Grzegorza przyśpieszyło decyzję przyjęcia chrztu. W dodatku utwór Grzegorza cechuje pomieszanie wątków, a nawiązaniu do ewangelicznej burzy towarzyszy relacja ze snu w którym jego matka, jak mitologiczna westalka, ocala statek z posągiem boga, sprowadza jego nawę do portu ${ }^{16}$. W Wyznaniach Augustyna, tak wrażliwego na różne wątki tradycji kulturowej, mamy także ten motyw. Bohaterką wydarzenia była jego matka Monika:

„Gdy okrętowi groziło zatonięcie, to właśnie ona dodawała otuchy marynarzom, tym do których podróżnicy nieobyci z morzem zwykle zwracają się o pomoc i pokrzepienie, ilekroć trwoży ich burza. Obiecała im bezpieczne przybicie do portu - Ty sam bowiem to jej obiecałeś w widzeniu" 17 .

13 Lukianus, Vita Demonacis 35, tłum. M. Bogucki: Lukian, Dialogi, II, Wrocław 1962, 185. O problemach żeglugi zimowej por. J. Rougé, La navigation hivernale sous l'Empire Romain, REA 57 (1955) 316-325; J. Jundziłł, Morskie przewozy pasażerów w epoce rzymskiej, „Nautologia” 26 (1991) z. 3/4, 1-7.

${ }_{14}$ Por. Plutarchus, Pompeius 50; Regum et imperatorum apophtegmata 11, 204C.

15 Por. Sulpicius Severus, Dialogi III 9, 14, 1-2, tłum. P. Nowak, ŹM 8, 82.

${ }^{16}$ Por. Gregorius Nazianzenus, Oratio 18, 31; Carmina II 1, 1 (chodzi o mit zwiąany z inauguracją kultu Kybele - M. Jaczynowska, Religie świata rzymskiego, Warszawa 1987, 6263); Paulinus Nolanus, Epistula 49.

17 Augustinus, Confessiones VI 1, 1, CCL 27, 73, tłum. Z. Kubiak: Sw. Augustyn, Wyznania, Warszawa 1999, 137. 
Obraz przeciwieństw w tym opisie nabiera ostrości, skoro słaba i posunięta w latach kobieta uspokaja nawet zawodowych marynarzy.

Przedstawiony wyżej stereotyp zachowania ma jeszcze inny wariant, zaprezentowany przez Diogenesa Laertiosa:

„Gdy płynął raz z ludźmi bezbożnymi podczas burzy i okręt walczył z falami, a oni wzywali pomocy bogów powiedział: Zamilczcie, aby bogowie nie dostrzegli, że wy tu płyniecie" ${ }^{18}$.

Opowieść ta dotyczy Biasa z Priene, jednego z siedmiu mędrców greckich, działającego w VI wieku prz. Chr. i ilustruje jego twierdzenie głoszące, że jedną z najtrudniejszych rzeczy jest znoszenie przeciwności losu. Diogenes przy tym powołuje się na źródła współczesne Biasowi, co pokazuje długą tradycję tego przekazu. Sytuację wyjściową w tym przypadku mamy podobną: filozof na okręcie w czasie burzy, w otoczeniu przerażonych podróżnych wzywających pomocy bogów. Rozwiązanie natomiast jest diametralnie różne, ujmujące sytuację od strony poglądów Biasa. Trzon opowieści jest jednak identyczny.

Podobne zdarzenie prezentuje bajka Ezopa: podróżni w czasie burzy wzywali pomocy bogów, kajali się i byli przerażeni. Po minięciu niebezpieczeństwa wybuchnęli szaloną radością, zachowując się widać wręcz nieprzyzwoicie, skoro surowy sternik zauważył:

„Przyjaciele, tak trzeba się zachowywać, jak gdyby znowu, jeśli los zdarzy, miała nadejść burza"19.

Odrębny nurt reprezentują przykłady ilustrujące przeciwną postawę filozoficzną, a właściwie jej brak. Dobrym przykładem jest tu fragment relacji Diogenesa o życiu Arystypa z Cyreny (435-350):

„Razu pewnego, kiedy płynął do Koryntu, na morzu rozszalała się burza. Ktoś z podróżnych, widząc jego zdenerwowanie, zauważył: «My, zwyczajni ludzie, nie boimy się, a wy, filozofowie, tchórzycie». To dlatego - odpowiedział Arystyp, że nie jest równa wartość życia, o które walczymy"20.

Wcześniej sytuację tę opisał w II wieku Aulus Geliusz i to w podwójnym wymiarze. Płynący z nim z Korkyry do Brundisium filozof nie zachował spokoju w czasie dość gwałtownej burzy, podczas gdy inni pasażerowie, między innymi bogaty i przyzwyczajony do zbytku Azjata, zdobyli się nawet na prowadzenie „doświadczeń” filozoficznych, obserwując zachowanie naszego filozofa.

18 Diogenes Laertios, Vitae philosophorum I 5, 86, thum. Żywoty, s. 55.

19 Aesopus, Fabula 308, thum. M. Golias: Bajki Ezopowe, Wrocław - Kraków 1961, s. 35, nr 80.

20 Diogenes Laertios, Vitae philosophorum II 8, 71, tłum. Żywoty, s. 116-117. Arystyp, przedstawiciel szkoły hedonistycznej, uczeń Sokratesa głoszący, że przyjemności cielesne są jedynym dobrem, stąd konieczna dbałość o zdrowie, por. A. Krokiewicz, Etyka Demokryta i hedonizm Arystypa, Warszawa 1960, 101-206. 
Wybrnął on z kłopotliwej sytuacji przytaczając właśnie anegdotę o Arystypie oraz wciągając Geliusza do dyskusji o poglądach Epikteta i innych stoików na temat „doznań duchowych”, które powodują takie stany, jakich właśnie doświadczał. Z kolei św. Augustyn streszcza tę relację Geliusza używając jego rozprawy do uzasadnienia własnych rozważań filozoficznych ${ }^{21}$.

Niezgodnie $\mathrm{z}$ ideałem postępowania filozofa zachował się także Cyceron w czasie ucieczki przed siepaczami Antoniusza. Nie mogąc znieść kołysania małego statku przybrzeżnego, wysiadł na ląd koło Caieta (dz. Gaeta), co przekreśliło jego szanse na ratunek. Nie inaczej postąpił i Seneka, który podczas krótkiej podróży po Zatoce Neapolitańskiej źle znosząc chorobę morską w czasie burzliwej pogody wyskoczył za burtę i popłynął wpław do skalistego brzegu. Sam przyznaje, iż prawie stracił przez to życie, mimo umiejętności pływackich. Seneka Starszy i Seneka Filozof nie uważają za wstydliwe ukazanie takiej dolegliwości ${ }^{22}$. Natomiast Lukian zdecydowanie potępił zachowanie cynika Peregrinosa (ok. 100-165), który tak dalece stracił filozoficzny spokój w czasie burzliwego rejsu po Morzu Egejskim, że według satyryka (i jego zaciętego wroga!), zawodził i płakał razem z kobietami ${ }^{23}$. Wzorce zachowań były więc płynne, a oceny zależne od okoliczności.

Z osobą Arystypa wiąże się u Diogenesa Laertiosa jeszcze jeden topos, dotyczący zachowań na morzu. Chodzi o przejścia spowodowane kontaktami z piratami, plagą mórz w czasach hellenistycznych i rzymskich. Wątki literackie grupują się przy tym w wybranych okresach, czasach Grecji klasycznej, epoce hellenistycznej i wojen z piratami u schyłku republiki ${ }^{24}$.

Arion z Metymny na Lesbos (VII/VI prz. Chr.), sławny wirtuoz gry na lutni, wypłynął statkiem do Koryntu z ogromną sumą pieniędzy zgromadzoną dzięki występom. Po drodze załoga zbuntowała się chcąc zabić poetę z powodu jego pieniędzy. Arion wybłagał jedynie zgodę na pożegnalny występ i gdy pozwolono mu wejść na rufę skoczył do morza. Uratował go jednak delfin, na którym dotarł do wybrzeży Peloponezu. W dodatku, gdy piraci zawinęli do Koryntu, w którym przebywał poeta, zostali zdemaskowani, a Periander nakazał ich stracić. Historia ta była popularna, pisali o niej między innymi Herodot i Owidiusz, także z powodu roli, jaką odegrał w niej delfin, jedno z najpopularniejszych zwierząt morskich w starożytności. Recepcję tego motywu mamy też poświadczoną przez Augustyna, który umieszcza Ariona obok takich cudownie ocalonych bohate-

${ }^{21}$ Por. Aulus Gellius, Noctes Atticae XIX 1-21; Augustinus, De civitate Dei IX 4, 2; Hieronim (Contra Rufinum III 30) wykorzystuje taką sytuację do ataku na swego ideologicznego wroga Rufina.

22 Por. Seneca Rhetor, Suasoriae VI 17; Seneca, Epistola 53, 1-4; Appianus, Historia Romana XVI 19, 73.

23 Por. Lukianus, Peregrinus 43.

${ }^{24}$ Por. H.A. Ormerod, Piracy in the ancient World, Liverpool 1924; T. Łoposzko, Starożytni piraci Morza Śródziemnego, Lublin 1994. 
rów Starego Testamentu, jak Dawid i Jonasz, a w ujęciu Jana Chryzostoma sytuacja ta stała się alegorią niemożności skutecznego działania w niebezpieczeństwie, gdy ktoś czyha tylko na niewłaściwe posunięcie sternika - biskupa ${ }^{25}$.

Z kolei Arystyp odbywając kiedyś podróż morską zorientował się poniewczasie, że znajduje się na statku pirackim. Chcąc uratować życie, jakby przez nieuwagę wyrzucił posiadane pieniądze za burtę, tłumacząc następnie:

„Lepiej, żeby pieniądze zginęły przez Arystypa, niż żeby Arystyp miał zginąć przez pieniądze" 26 .

Natomiast Bion z Borystenes (III wiek prz. Chr.) był na tyle zarozumiały, iż uważał, że dostateczną obroną przed piratami, w których towarzystwie przypadkowo znalazł się na morzu, jest jego imię, podczas gdy jego towarzysze drżeli na myśl, że zostaną rozpoznani ${ }^{27}$. Bionowi udało się wybrnąć z kłopotów, natomiast niewoli nie uniknęli cynik Diogenes z Synopy (413-323) oraz Platon, wykupiony dopiero przez przyjaciół po powrocie z niefortunnej misji na Sycyliii ${ }^{28}$.

Kłopoty filozofów związane $\mathrm{z}$ morzem na tym się nie kończą. Zenon z Kition (333-261) podobno wtedy związał się z filozofią, gdy stracił bardzo cenny, całookrętowy ładunek purpury, wyrażając zresztą zadowolenie, że bieda skierowała go na drogę filozofii ${ }^{29}$.

Standardowym tematem filozoficznych rozważań stała się także sytuacja szukania sposobu ratunku w czasie katastrofy morskiej. Rozważano mianowicie, czy filozof ma prawo wydrzeć deskę z rozbitego statku stanowiącą „koło ratunkowe" mniej uczonemu, by samemu uratować się dzięki niej dla dobra ludzkości. Epizod katastrofy morskiej posłużył nawet Witruwiuszowi do gloryfikacji nauki i fachowości:

„Kiedy Arystyp, filozof ze szkoły Sokratesa, wyrzucony jako rozbitek na wybrzeża rodyjskie zauważył tam nakreślone figury geometryczne, miał podobno zawołać do towarzyszy: «Bądźmy dobrej myśli! Widzę bowiem ślady ludzi»"30.

25 O Arrionie zob. Fronto, Epistulae, ed. M.P.J. Hout, Leipzig 1988, 241-242, tłum. S. Stabryła w: Nowele rzymskie, Warszawa 1979, 390-391; Herodotus, Historiae I 23-24; Ovidius, Fasti II 95 101; Aulus Gellius, Noctes Atticae XVI 19; Hyginus, Fabulae 194; Augustinus, De civitate Dei I 14; Joannes Chrysostomus, De sacerdotio III 15; por. P. Grimal, Stownik mitologii greckiej i rzymskiej, Warszawa 1987, 41-42; o delfinach, zob. J.C. Cooper, Zwierzęta symboliczne i mityczne, thum. A. i L. Ryś, Poznań 1998, 44-46.

${ }^{26}$ Diogenes Laertios, Vitae philosophorum II 8, 78, tłum. Żywoty s. 120.

27 Por. tamże IV 7, 50, thum. Żywoty s. 243.

28 Por. tamże VI 2, 74 tłum. Żywoty s. 349 (Diogenes); Cicero, De natura deorum III 34, 83; o Platonie np. Nepos, Dion 2; Hieronymus, Epistula 53, 1.

${ }^{29}$ Por. Plutarchus, De tranquilitate animi 6; Diogenes, Vitae philosophorum VII 1, 2 i 4; Seneca, De tranquilitate animae 14,3. Historię tę powtarzano ciągle aż do okresu późnego cesarstwa por. Basilius, Epistula 4.

${ }^{30}$ Vitruvius, De architektura VI Prol. 1, tłum. K. Kumaniecki: $O$ architekturze, Warszawa 1956, 101. Problem katastrofy w tym kontekście postawił po raz pierwszy stoik Hekaton (II wiek 
Wykładał on następnie w rodyjskim gimnazjum z takim powodzeniem, że zdobył majątek. Kiedy jego towarzysze odpływali do ojczyzny polecił powiedzieć:

,że dzieciom powinno się dawać takie skarby i tak je zaopatrywać na drogę, aby w razie rozbicia okrętu mogły z tym wszystkim wypłynąc na powierzchnię wody" ${ }^{31}$

- dotyczyło to rzecz jasna wiedzy. Znalezienie się w nieomal takiej samej sytuacji przypisał Fedrus i Simonidesowi (556-468), poecie - mędrcowi z Keos. Gdy inni pasażerowie w obliczu bliskiego rozbicia obciążali się kosztownościami, on nie starał się czegokolwiek ratować. Na brzegu rozbitków obrabowano, ale Simonidesa, dzięki jego sławie, wielbiciel z pobliskiego miasta szczodrze ugościł i obdarował ${ }^{32}$.

Stereotyp występujący w biografiach filozofów i innych sławnych ludzi z przeszłości, zwłaszcza greckiej, najpewniej w większości anegdotyczny, przeniesiono na życiorysy ludzi działających w czasach bliższych cesarstwu lub cesarzy rzymskich. Duże możliwości tkwiły pod tym względem w zmitologizowaniu życiorysu Aleksandra Wielkiego i innych wielkich postaci czasów hellenistycznych, ale tak się nie stało; mamy jedynie kilka nikłych epizodów, jak np. ten dotyczący Antygona Gonatesa, króla Macedonii (319-239):

„Kiedy w bitwie morskiej pod Kos jeden z jego przyjaciół powiedział: «Nie widzisz, o ile liczniejsze są okręty nieprzyjacielskie»? - odrzekł «A mnie, to na ile z nich rachujesz»?"33.

prz. Chr.), powtarza za nim Cyceron (De officiis III 10, 42), motyw ten był także popularny w literaturze patrystycznej np. Ambrosius, De offices ministrorum III 27; por. J. Jundziłł, The ways of salvage from the shipwrecks in the Roman times, „Antiquitas” 18 (1993) 81-88.

31 Vitruvius, De architektura VI prol. 1, thum. K. Kumaniecki: $O$ architekturze, Warszawa 1956, 101.

${ }^{32}$ Por. Valerius Maximus, Factorum et dictorum memorabilium libri I 7, ext. 3; Fedrus, Fabulae IV 23; por. M. Komornicka, Simonides z Keos, poeta i mędrzec, Wrocław 1986. Inne związki biografii filozofów z morzem to np. śmierć w katastrofie morskiej Protagorasa z Abdery (480-411); niechęć Sokratesa do podróży morskich - Diogenes, Vitae philosophorum II 5, 23; IX 8, 55-56 lub anegdota dotycząca Antystenesa (440-366): „Młodzieńca z Pontu, który obiecywał mu wyświadczyć wielką przysługę, jeżeli przepłynie okręt z solonym mięsem, wziął ze sobą i zaprowadził z próżnym workiem do handlarki mąką, worek mąką napełnił i odszedł. Gdy zaś handlarka zażądała zapłaty, powiedział: «Ten młodzieniec zapłaci, jeżeli okręt z solonym mięsem przypłynie»" (Diogenes Laertios, Vitae philosophorum VI 1, 9, thum. Żywoty, s. 315); por. także burza morska w życiorysie Asklepiadesa - tamże II 17, 130. Pitagoras wiele podróżował morzem, a biografowie wiążą z nim nawet zdolność uciszania fal morskich i przepowiednie co do przebiegu rejsów, por. Valerius Maximus, Factorum et dictorum memorabilium libri VIII 7, ext. 2-3; o Platonie zob. Diogenes Laertios, Vitae philosophorum III 18-22, a w bagażach Arystotelesa po zakończeniu rejsu celnicy znaleźli podobno 300 naczyń przewożonych nielegalnie, por. Theodoretus, Graecarum affectionum curatio XII 51.

${ }^{33}$ Plutarchus, De se ipsum laudatio 16; A. Swiderek, Hellada królów, Warszawa 1969, passim (spec. 21-22). 
Gorsze doświadczenia z morzem miał Pyrrus (319-272) władca Epiru, który został ukarany przez bogów za ograbienie świątyń Lokrii rozbiciem floty wojennej, z czego sam ledwo wyszedł żywy ${ }^{34}$.

Podobnie mało znaczące są ślady nadawania głębszych znaczeń poczynaniom osobistości rzymskich z czasów republiki. Wyjątkiem był Scypion, który próbował wykorzystać propagandowo sukcesy w oblężeniu Nowej Kartaginy, aby mianować się poskromicielem mórz i synem Neptuna. Dopiero epoka wojen domowych przynosi nieco więcej opisów podobnych postaw. W wyniku interwencji boskiej miał na przykład ocaleć z katastrofy morskiej Appiusz Klaudius Pulcher (I wiek prz. Chr.) - postać jak i cały ród często mitologizowana w historiografii rzymskiej ${ }^{35}$. Powtarzana przez wielu historyków była relacja z próby przeprawy Cezara z Apolonii do Brundisium po posiłki wojskowe. W czasie burzy rzeka Aoosta, którą chciał wypłynąć na Adriatyk, zaczęła burzyć się przy ujściu do morza, tworząc niebezpieczne dla małego statku wiry. Nawet sternik chciał zawrócić, ale wódz stwierdził tylko: „Czego się boisz? Wieziesz Cezara!” i załoga ustąpiła z próby przebicia się na morze dopiero wtedy, gdy statek zalewały już fale ${ }^{36}$.

Pomyślniej skończyło się inne zdarzenie, które miało miejsce w czasie przeprawy przez Hellespont. Płynąc na niewielkich statkach Cezar napotkał flotę Kasjusza złożoną z 70 okrętów. Na zdecydowane wezwanie i pod wrażeniem jego zwycięstwa pod Farsalos poddała się ona bez oporu, choć łatwo byłoby zdusić teraz przeciwnika. Innym razem wbrew przewidywaniom wyprawił się w zimie z flotą do Afryki i zwyciężył przeciwników w grudniu 36 r., nie mówiąc już o wyczynie pływackim, który umożliwił mu ratunek z oblężonej latarni morskiej Faros, kiedy to wpław dostał się na własne okręty. Znane są też przechwałki Cezara, odnoszące się do poczynań jego wojsk na morzu w czasie kampanii galijskiej, zwłaszcza w bitwie z Wenetami i jego apologia własnych dokonań morskich w czasie wyprawy do Brytanii ${ }^{37}$.

W życiorysie Cezara, który ze względu na swe niepospolite dokonania stał się szybko dla Rzymian na pół legendarny, odnajdujemy także przejścia z piratami. Między innymi pisano, że w czasie podróży do Bitynii w 81/80 r. (lub na Rodos w 76 r.) został schwytany przez piratów. W czasie gromadzenia okupu, a miał on wynosić 50 talentów, zachowywał się bardzo swobodnie, jak

34 Por. Appianus, Historia Romana III 8-12; Valerius Maximus, Factorum et dictorum memorabilium libri I 1, ext. 1 .

35 Por. Valerius Maximus, Factorum et dictorum memorabilium libri VIII 1, absol. 4.

${ }^{36}$ Lucanus, Pharsalia V 580; Valerius Maximus, Factorum et dictorum memorabilium libri IX $8,2$.

37 Por. Appianus, Historia Romana XIV 57, 235-237; Florus, Epitome I 13 (thum. I. Lewandowski, Wrocław - Warszawa 1973); Plutarchus, De fortuna Romanorum VI 319B-D; tenże, Regum et imperatorum apophtegmata I 205F i IX 206C; Minucius Felix, Octavius 26, 4; Iulius Caesar, Bellum Gallicum III 9-16; Plutarchus, Caesar 23. 
wódz, grożąc często skazaniem piratów na śmierć. Po uwolnieniu szybko zebrał flotę i dopełnił tego, co przyrzekł. Jak pisze Swetoniusz, chyba z niezamierzonym cynizmem:

„Lecz nawet w zemście okazywał niezwykłą łagodność usposobienia. Oto ponieważ w czasie niewoli u piratów przysiągł sobie, że ich kiedyś przybije do krzyża, więc gdy wreszcie dostał ich w swe ręce kazał najpierw zabić, a potem dopiero ukrzyżować" 38 .

Podobnie godnie, choć nie tak przedsiębiorczo, przyjął doświadczenia dwukrotnej burzy morskiej w drodze na Samos jego przybrany syn - Oktawian, choć znany był ze swych obaw przed morskimi podróżami. Epizody burz morskich występują także w biografii Klaudiusza, który na wyprawę do Brytanii ruszył statkiem prosto z Ostii, ale pod wpływem gwałtownych burz u południowych wybrzeży Galii zrezygnował z dalszej żeglugi i ruszył lądem nad Oceanus Britannicus (kanał La Manche). Marek Aureliusz pod wpływem przebytej burzy w drodze z Aten do Italii „sam włożył togę i polecił żołnierzom ubrać się w togi; za jego czasów żołnierze nigdy nie nosili płaszczy". Cesarz widocznie uznał swoją przygodę za ostrzeżenie bogów przed zmianą dawnych obyczajów rzymskich i na korzyść stylu życia filozofa greckiego ${ }^{39}$. Cesarze więc, w przeciwieństwie do wielkich indywidualności czasów republiki, raczej nie szczycili się dokonaniami na morzach. Czyżby zaważył przykład Augusta, wystrzegającego się kontaktu z tym żywiołem? Pewniejsze jest to, że gwarantując bezpieczeństwo dla gospodarczego wykorzystania morza, zlikwidowali motyw gloryfikacji bohaterskich czynów z nim związanych. Ważniejsze stało się budowanie portów, jak za Klaudiusza czy Trajana oraz pokojowe podróże inspekcyjne Hadriana.

Odmiany omawianego stereotypu literackiego pojawiały się dosyć często w różnych dziełach okresu hellenistycznego i za cesarstwa. Z pewnością zintensyfikowały go Ewangelie, głównie na polu literatury chrześcijańskiej oraz Vita Apollonii powodująca to samo w literaturze pogańskiej. Wielką rolę odegrały też wzory do ćwiczeń retorycznych, które często przechowywały pokazywane wyżej sytuacje. Częstotliwość ich używania i przeniesienie do biografii wielkich jednostek wskazują na siłę pierwiastka morskiego w kulturze greckorzymskiej.

${ }^{38}$ Suetonius, Caesar 4 i 74, tłum. J. Niemirska-Pliszczyńska: Swetoniusz, Żywoty ceazarów, Wrocław - Warszawa 1965, 33 i 85; Plutarchus, Caesar 1-2; Valerius Maximus, Factorum et dictorum memorabilium libri VI 9, 15; Welleius Paterculus, Historiae Romanae II 41-42; w rzeczywistości zaszło to w $74 \mathrm{r}$. w czasie powrotu z Rodos.

39 Por. Suetonius, Augustus 17; Claudius 17; Appianus, Historia Romana XIV 88, 368-372; Florus, Epitome II 13; Scriptores Historiae Augustae, Marcus Aurelius 37 (tłum. H. Szelest: Historycy Cesarstwa Rzymskiego, Żywoty cesarzy do Hadriana do Numeriana, Warszawa 1966); Minucius Felix, Octavius 26, 4; zob. J.M. Roddaz, Marcus Agrippa, Roma 1984; M. Reddé, Mare Nostrum, Roma 1986. 


\title{
THE SEA AS A CHALLENGE FOR GODS AND PEOPLE
}

\author{
(Summary)
}

The paper contains a collection of sea voyages motifs and experiences of famous people. It demonstrates how this environment perceived as exceptionally dangerous was used as a power attribute of gods by classical, Greek and Roman writers. The starting point is the gospel description of a sea storm although the use of the sea as a test of courage concerned many mythological heroes, famous philosophers, politicians and leaders known from the history of Greeks and Romans. These motifs continue until the creation of the works of the Church Fathers, who were able to use them successfully for their own purposes (Augustine, Gregory z Nazianzus, Pauline of Nola) that is praising the power of God but also demonstrating their own bravery. 